\title{
Demographic Situation of the Czech Republic - The Current Situation and the Main Goals for the Future
}

\begin{abstract}
The main aim of the article is to analyze the demographic situation of the Czech Republic and to present the prospects for Czech demography in the coming years. The text is divided into sections related to the most important components of the demographic situation - population size and factors that influenced it in the past (e.g. the baby boom phenomenon), live births, the structure of the aging society in the Czech Republic ( there are more people aged $65+$ than in the age group $0-14$ ), deaths (caused largely by cancer and cardiovascular diseases). An important part of the analysis is the problem of external migration. The article was prepared on the basis of data from the Statistical Yearbook (Statisticka Rocenka Česke Republiký), published by Český Statistický Úřad (CSU). The text ends with conclusions and recommendations on demography. The author believes that the demographic problems of the Czech Republic are part of the overall demographic problems of the European Union, such as the low fertility rate (TFR), which is still far from the simple replacement of the generations. The result is an ageing European population, which will have a negative impact on the economy, social systems and external policies.
\end{abstract}

Key words: Demography, Total Fertility Rate, Deaths, Population, Ageing Population

\section{Introduction}

Demographic situation - despite its importance for us as humans, is often treated with much less attention than it deserves. Politicians rarely treat demographic issues seriously, which is not a good attitude, because positive demographic indicators determine the survival of mankind.

^Adrian Moliński - University of Warsaw, e-mail: a.molinski@student. uw.edu.pl. 
Demographic situation of European Union mainly depends on the demographic condition of it member states - it is not constant; it changes every time EU accepts new member states.

Nowadays one of the main problems in demographic structure of the European Union is its low total fertility rate. ${ }^{1}$ The estimated data yielded by Eurostat shows, that total fertility rate in the EU is 1.6, while the ideal demographic state -replacement level fertility stands at 2.1 children per woman. At the moment there is no member state that achieves replacement level fertility. Closest to this state is France, where the total fertility rate is the highest of all EU's member states - 1.92, according to Eurostat dates.

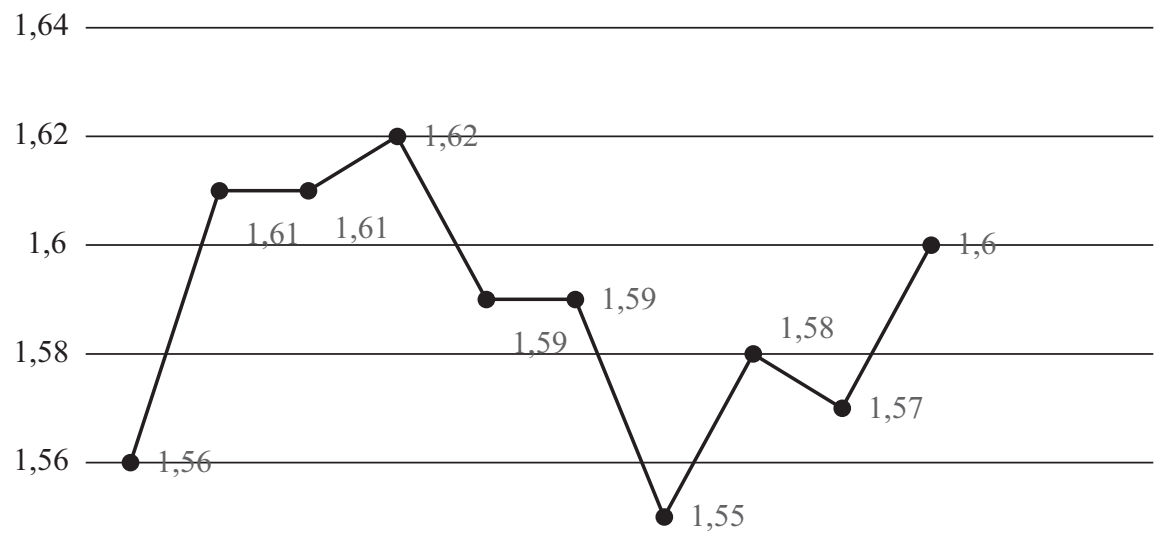

\section{$1,5 \quad \begin{array}{llllllllll}2007 & 2008 & 2009 & 2010 & 2011 & 2012 & 2013 & 2014 & 2015 & 2016\end{array}$}

Fig. 1. Total Fertility Rate in the European Union (2007-2016)

Source: own elaboration based on Eurostat data.

Another significant demographic issue for the European Union is population ageing - this problem concerns most countries in the world. As it is presented on graph 1.2, according to Eurostat data, social structure

${ }^{1}$ Definition from CIA World Factbook: Total Fertility Rate gives a figure for the average number of children that would be born per woman if all women lived to the end of their childbearing years and bore children according to given fertility rate at each age. 
has changed significantly in the last 15 years. Population decreased in every age range starting from ages $0-5$, to ages $40-44$, and it increased in all ranges from $45-48$ up to the peak of this pyramid $-85+$. It is worth noticing, that the number of men in the age range of $85+$ has doubled. This state of demographic indicators is worrisome - even if demography depends on policy of EU Member States, EU authorities must analyze this situation and create long term recommendations aimed at improving the demographic situation in the European Union.

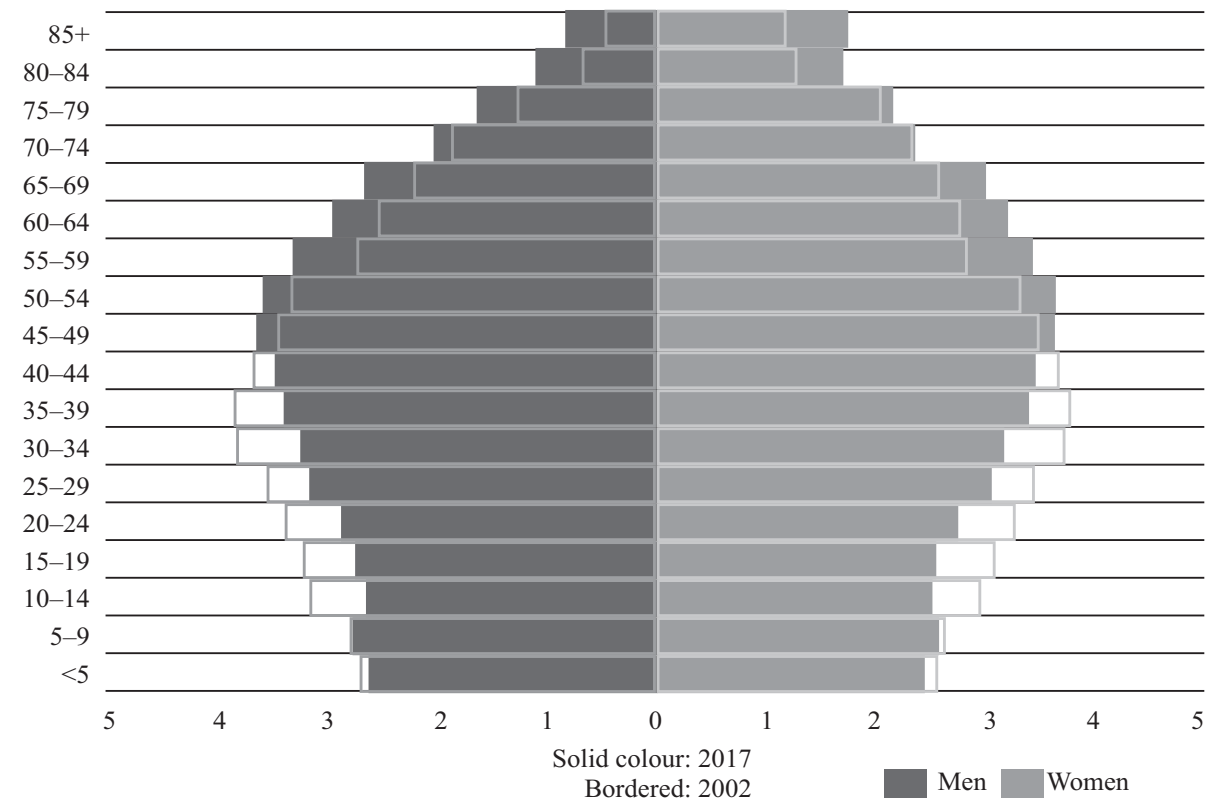

Fig. 2. Population Pyramid of EU-28

Source: Eurostat.

There is no member state in the EU, which has ideal demographic situation, but Czech Republic is an example of a country that manages to handle the demographic situation pretty well, despite the negative tendencies in Europe and around the world.

\section{Czech Republic - Population}

Czechia is a country situated in Central Europe. It covers an area of almost 79000 sq kilometres. Czech Republic's neighbours are Poland in the northeast, Slovakia in the east, Austria in the south and Germany in the west. The population of Czechia has been dynamically increasing since the end of WWII (in 1947 the population of Czech Republic 
was approx. $8.8 \mathrm{mln}$ people). Nowadays, as we can see on graph 1.3, it is on the highest level in the last 60 years. Since 1950's, a decrease in the population was not commonly observed in this country. Between 1980 and 1997 we the population was almost constant, with a little increase, then little fall between 1989 and 1992. The main factors which affected the Czech Republic population were baby booms. The Czechs were dealing with two baby booms - one in 1974 (the so called Husak's Children), and another baby boom starting in the early 2000's which ended in 2009.

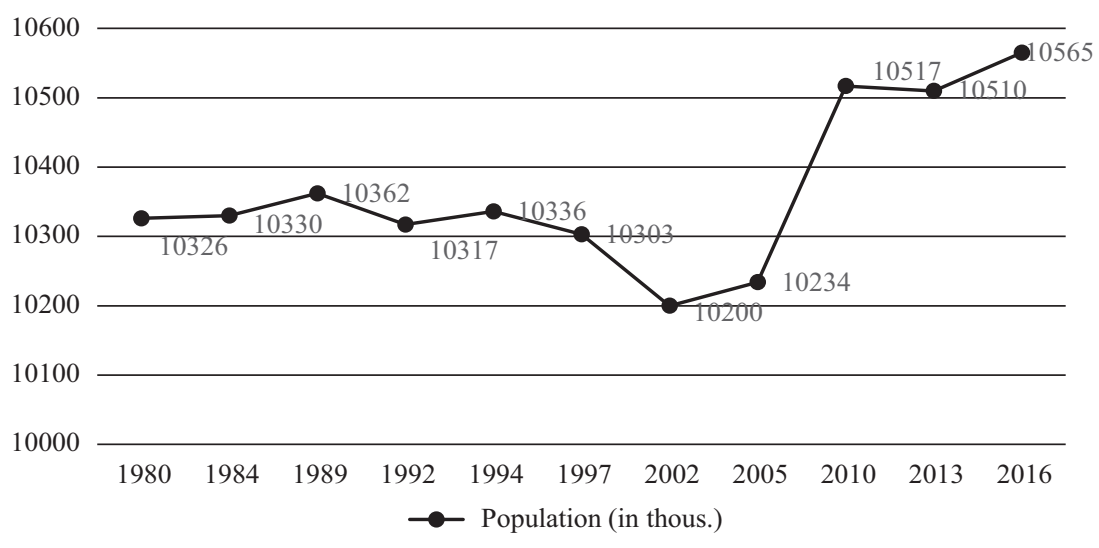

Fig. 3. Population of the Czech Republic (1980-2016)

Source: own elaboration based on Statisticka Rocenka Česke Republiký, Český Statistický Uřad, 2017, p. 126.

\section{Live Births}

Speaking of baby booms, we move on to live births. The data on the graph 1.4 shows the latest baby boom clearly. In 1999 the number of live births reached the lowest point since decades - fewer than 92 thousand children were born. The next decade saw a significant change in the live births indicator- as we can see, in 2008 there were 119 thousand live births. That was the last year that this indicator was that high. In 2016 the number of live births was still pretty high, but not as high as in 1980s.

\section{Ageing Population}

The Czech Republic did not avoid the problem of population ageing. In this graph we can see, that there are more Czechs aged $65+(18.8$ per cent) than kids in the $0-14$ age group ( 15.6 per cent), while those aged between $15-64$ constitute 65.6 percent of population. It is a real challenge 
A. Moliński, Demographic Situation of the Czech Republic...

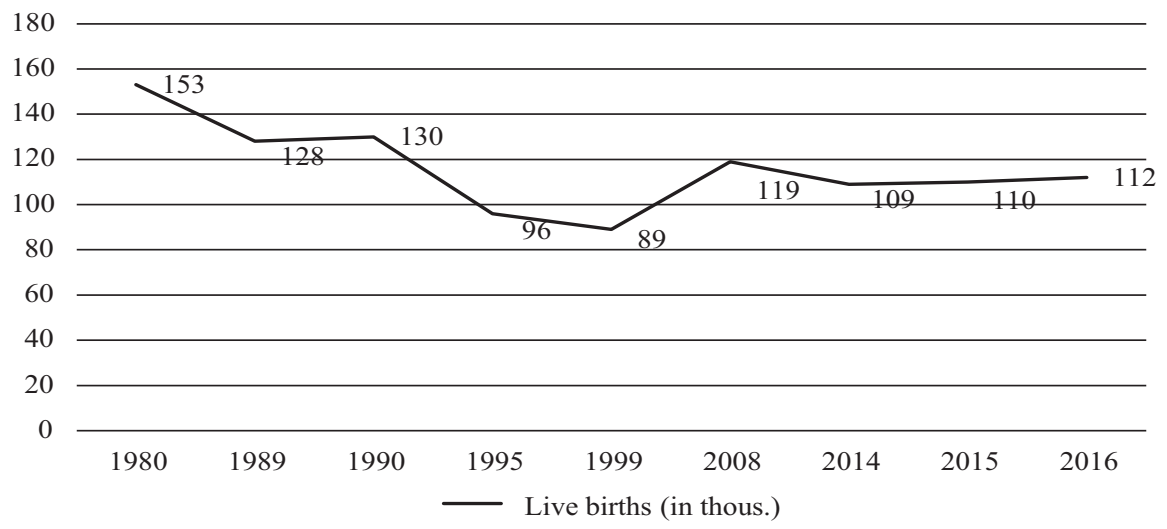

Fig. 4. Live births in the Czech Republic (1980-2016)

Source: own elaboration based on Statisticka Rocenka Česke Republiký, Český Statistický Úřad, 2017, p. 137.

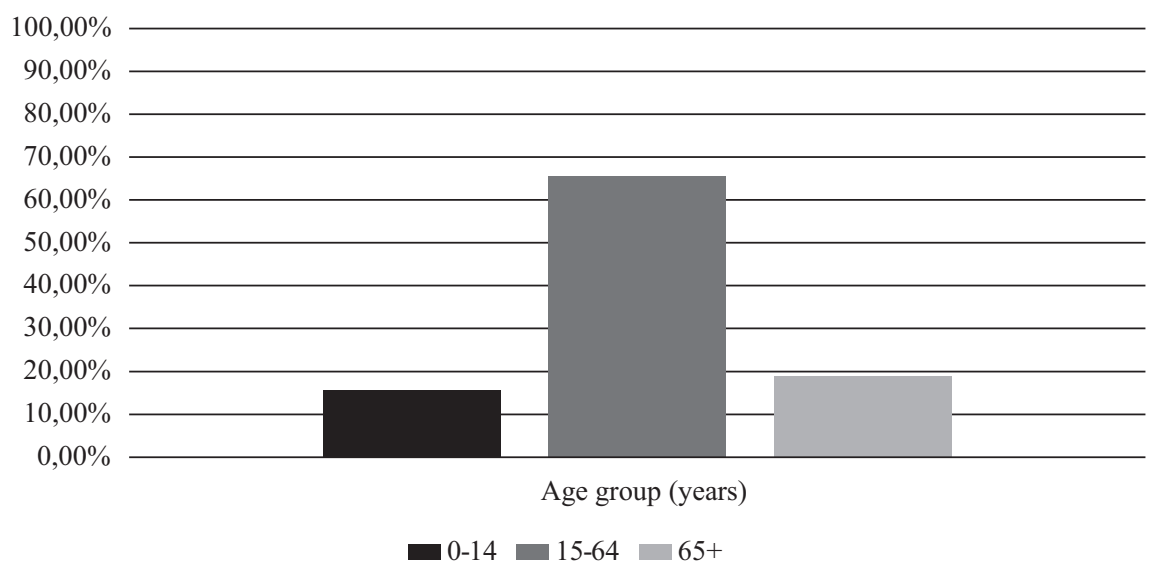

Fig. 5. Population structure in the Czech Republic (2016)

Source: own elaboration based on Statisticka Rocenka Česke Republiký, Český Statistický Úř́ad, 2017, p. 130.

in terms of the demographic situation of Czech Republic - a closer look at the forecast data from United Nations shows that in 2050 the population of our neighbours is expected to be lower than 9 million. ${ }^{2}$

2 Official United Nations Site: http://www.un.org/esa/population/publications/ worldageing19502050/pdf/076czech.pdf (15.10.2018). 


\section{Deaths}

Next we will move on to another important indicator of demographic studies - deaths. We can observe, that from 1980 to 2014 the number of deaths decreased from 135 thousand to 105 thousand ${ }^{3} \operatorname{In} 2016$ that number was a little bit higher, but not significantly. The most common causes of death are - like in Poland and other countries in the World - diseases of the circulatory system and neoplasms.

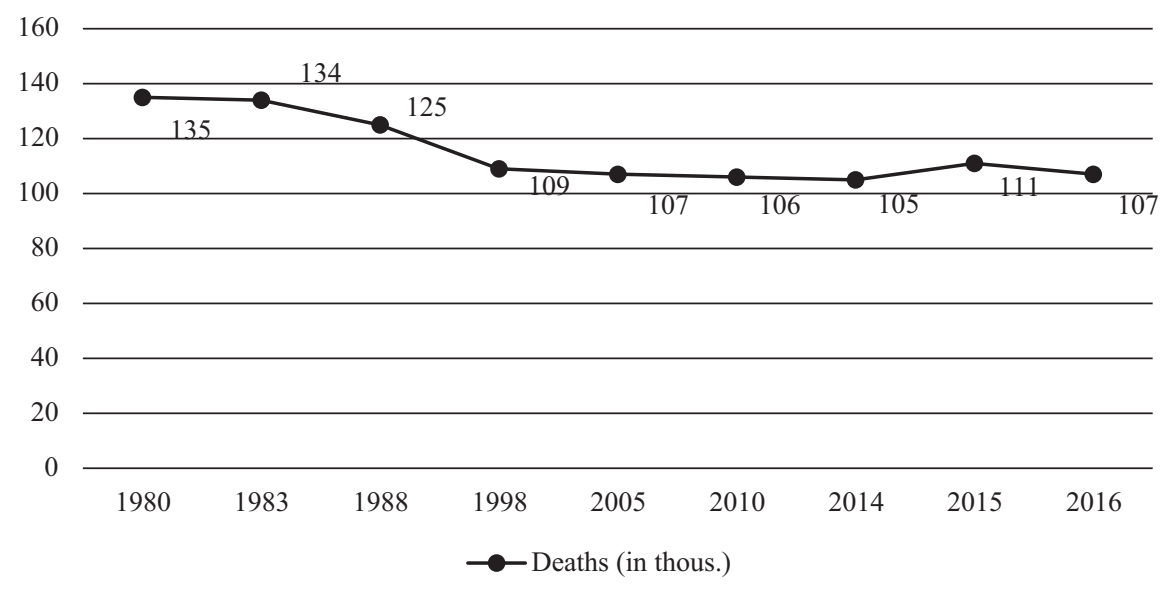

Fig. 6. Deaths in the Czech Republic (1980-2016)

Source: own elaboration based on Statisticka Rocenka Česke Republiký, Český Statistický Ứad, 2017, p. 126.

\section{International Migration}

International migrations - in the case situation of Czech Republic the situation is good - fewer people leave the country, because they are satisfied with their standard of living and more people come to Czech Republic in search of a better life. As we can see on the graph, Czechia's net migration is positive. In 2000 there were 7 thousand immigrants and 1 thousand emigrants; in 2015 it was 29 thousand to 25 thousand, but the main change can be attributed to a different method of counting migrants - in 2000 it was migrants with permanent residence and for 2015 migration is counted when migrants reside in the country for at least twelve months, and that data is estimated. ${ }^{4}$ We can expect that

3 Statisticka Rocenka Česke Republiký, Český Statistický Úřad, 2017, p. 126.

4 Demographic Yearbook of Poland, 2017, Central Statistical Office, p. 508 
A. Moliński, Demographic Situation of the Czech Republic...

immigration will drop, because Milos Zeman, and Andrej Babis - President and Prime Minister of Czechia are against accepting immigrants in their country.
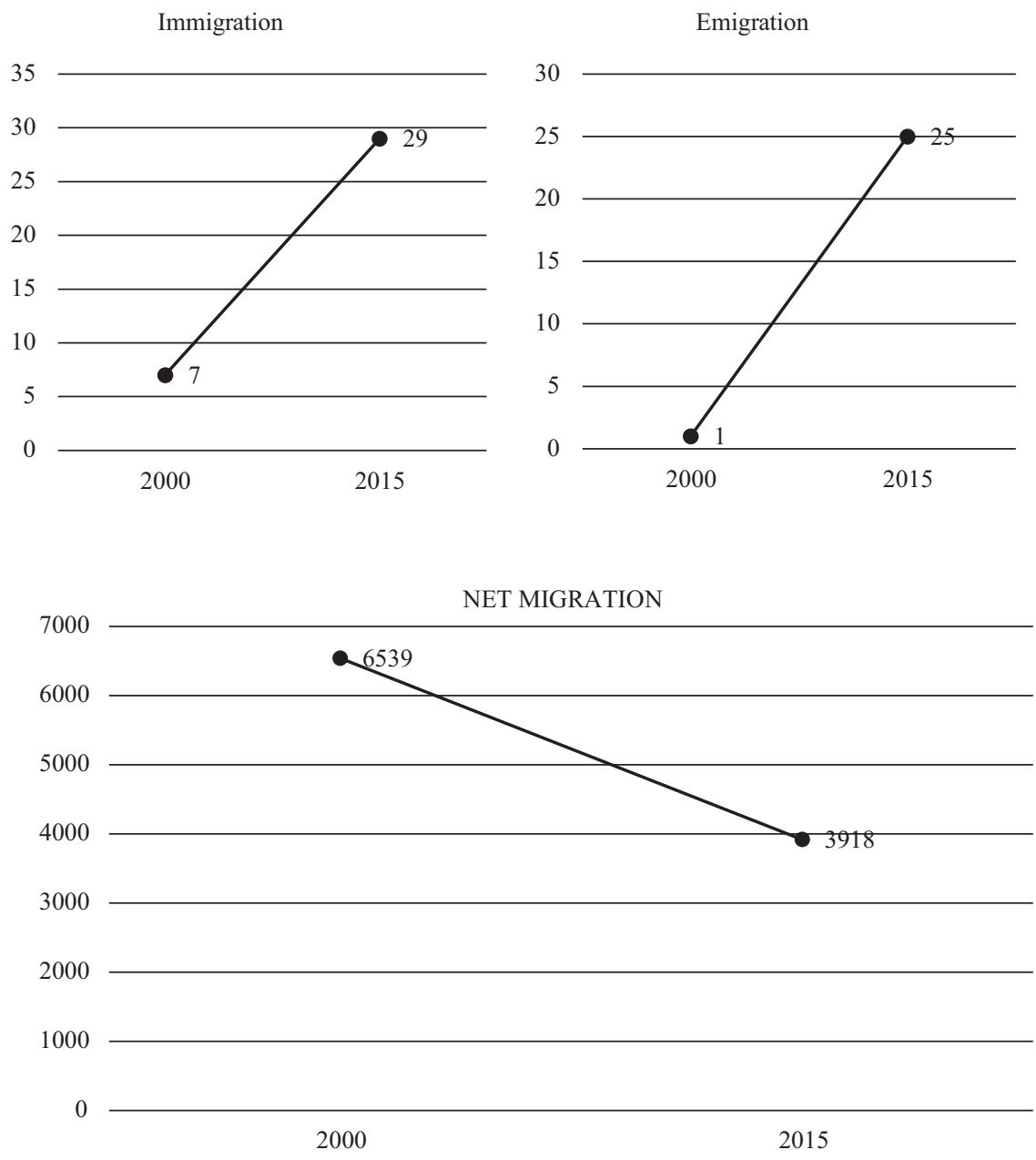

Fig. 7. Migration in the Czech Republic

Source: own elaboration based on Demographic Yearbook of Poland, 2017, Central Statistical Office, p. 508, estimated data. 


\section{Main Goals for the Future}

There are a few recommendations for the future that Czech Republic can implement to improve their demographic situation. First of all it is important to promote healthy lifestyle and regular medical examinations - especially in case of diseases of the circulatory system and neoplasms the number of deaths could be lower if people took care of their health. Maybe healthy lifestyle is hard to promote and adapt, but promotion of regular medical examinations is crucial to early detection and treatment of circulatory system diseases and all forms of cancer. Czech Republic's health care is on the highest level - people from this country must take advantage of it, because high level health care is very valuable to enable a country to build a strong and healthy society.

Long term pro family policy is necessary for increasing the births indicator. In Czech Republic total fertility rate, which is the average number of children born per women, is 1.4. 1.4 children per 1 woman, when as author wrote before - the Replacement Level Fertility - the ideal demographic state is 2.1 children born per woman. It is necessary to improve it by creating special long term pro family policies.

Population ageing is a dangerous threat to our future, but there is an opportunity to make people aged $65+$ more active on the labour market - even after retirement - a large group of these people can still work. It is important, to work on something that we call silver economy ${ }^{5}$ - using the potential of older people, because they can be effective participants in the community.

The last recommendation is to ensure maintaining a positive situation in the area of migration - like I said before, Czech Republic situation in this example is positive, but nothing lasts forever - it is necessary to monitor the migrant situation, encourage potential emigrants to stay and promote Czech Republic as a good place to live. It can be problematic, because Czechia's authorities implement policies which are strictly against new immigrants.

\section{References}

CIA World Factbook: https://www.cia.gov/library/publications/the-worldfactbook/.

Demographic Yearbook of Poland, 2017, Central Statistical Office.

5 Silver Economy is explained in European Commission materials: https:// ec.europa.eu/digital-single-market/en/news/silver-economy-study-how-stimulateeconomy-hundreds-millions-euros-year (15.10.2018). 
European Commission materials: https:/ec.europa.eu/digital-singlemarket/en/news/silver-economy-study-how-stimulate-economy-hundredsmillions-euros-year.

Eurostat database: https://ec.europa.eu/eurostat/data/database.

Holzer Z.J., Demografia (Demography), Polskie Wydawnictwo Ekonomiczne PWE, Warszawa 2003.

Official United Nations Site: http://www.un.org/esa/population/publications/worldageing19502050/pdf/076czech.pdf.

Potrykowska A., Strzelecki Z., Polska w Europie-Przysztość demograficzna. Sesja Inauguracyjna (Poland in Europe - The demographic future. Inauguration session), t. I, Zakład Wydawnictw Statystycznych, Warszawa 2012.

Statisticka Rocenka Česke Republiky, Česky Statisticky Uřad, 2017. 